\title{
Logical Empiricism, Politics, and Professionalism
}

\author{
Scott Edgar
}

(C) Springer Science+Business Media B.V. 2007

\begin{abstract}
This paper considers George A. Reisch's account of the role of Cold War political forces in shaping the apolitical stance that came to dominate philosophy of science in the late 1940s and 1950s. It argues that at least as early as the 1930s, Logical Empiricists such as Rudolf Carnap already held that philosophy of science could not properly have political aims, and further suggests that political forces alone cannot explain this view's rise to dominance during the Cold War, since political forces cannot explain why a philosophy of science with liberal democratic, anti-communist aims did not flourish. The paper then argues that if professionalization is understood in the right way, it might point toward an explanation of the apolitical stance of Cold War philosophy of science.
\end{abstract}

Keywords Logical Empiricism · Carnap · Reisch · Cold War · Professionalization

\section{Introduction}

Philosophers of science, by and large, do not turn up in the pages of The New Republic arguing about biases built into the inspection procedures of the International Atomic Energy Agency (IAEA), or the values informing the Federal Drug Agency's (FDA) decision to make a contraceptive available over the counter. Philosophy of science has nothing to do with public policy, global or domestic, and besides, The New Republic is too popular a magazine for what philosophy of science is about. Pieces about the IAEA or the FDA in The New Republic are just not the sorts of articles written by philosophers of science.

A growing body of literature in history of philosophy of science aims, in a sense, to explain why not. That is, it aims to explain why the dominant philosophy of science in

S. Edgar $(\bowtie)$

Philosophy, University of Penssylvania, 433 Logan Hall, Philadelphia, PA 19104, USA

e-mail: sedgar@sas.upenn.edu 
America in the 1930s, a politically and culturally engaged philosophy, was displaced in the 1950 s by the technical, culturally disengaged, and strictly apolitical philosophy that most now associate with Logical Empiricism. George A. Reisch's How the Cold War Transformed Philosophy of Science, ambitious in both its scope and the granularity of its historical detail, is a very welcome addition to this literature.

Reisch argues that Logical Empiricist philosophy of science in the 1930s aimed to marshal the formal, natural, and social sciences in the service of Enlightenment, leftleaning ideals such as pluralism, internationalism, and social progress. But as a consequence of Cold War political forces in the late 1940s and 50s, Logical Empiricism shed its cultural and political aims, and the dominant philosophy of science became politically neutral and focused on technical questions of logical analysis. Reisch's account explains a great deal about how philosophy of science changed in response to Cold War political forces. In particular, it explains how in the 1950s those forces helped marginalize the Unity of Science movement, which had been started by Otto Neurath and continued by Philip Frank following Neurath's death in 1945.

But I want to suggest that Reisch's account does not completely explain why philosophy of science became politically neutral, rather than trading its 1930 s collectivist and internationalist politics for the politics of Cold War liberalism. One place to look for this explanation is in the idea that philosophy of science underwent a wave of professionalization in the 1950s, and that this is somehow related to its political disengagement. But this idea's usefulness depends on what we take professionalization to be. Here, I think, Reisch's account is very helpful. His account of the changes in Cold War philosophy of science invites us to consider a model of professionalization that is useful in just this sense: while the right model of professionalization cannot by itself explain anything about philosophy of science's apolitical stance, it will point us to where those explanations might be found.

\section{The Place of Politics In (or Out) of Logical Empiricist Philosophy of Science}

We need to start with a little more detail about Reich's account of Cold War influences on philosophy of science. The Logical Empiricists were committed to the modernist idea that rationally and scientifically planned government policy could be a powerful instrument of social progress. Neurath had worked as an economic planner in the short-lived Bavarian Republic. But the 1950s in America saw the rise of anti-intellectual and anti-collectivist ideologies, both of which were hostile to the idea of scientific planning in politics or economics. Reisch also argues that the Logical Empiricists were committed to a pluralistic conception of value. But the Cold War in America saw individual freedom become an absolute value, a value that could never be weighed against others, such as peace or international cooperation. Besides these changes in the background intellectual environment, the Cold War also saw changes in the politics of the university and of philosophy. As professors were required to sign loyalty oaths as a condition of appointments, leading lights of the Logical Empiricist movement were red-baited by colleagues and investigated by the FBI as possible Soviet sympathizers. In this context, the culturally and politically engaged project of the movement was marginalized. Neurath, the politically engaged project's first and most full-throated advocate, died in 1945. Frank, Neurath's successor as standardbearer of this project, was marginalized over the course of the 1950s.

By the early 1960s, a very different kind of philosophy of science was dominant. With Rudolf Carnap's and Hans Reichenbach's work in probability theory and Carl Hempel's 
work on confirmation and explanation, philosophy of science had become a more exclusively technical discipline. But more than that, it had become strictly apolitical, as well: it no longer had Neurath's or Frank's cultural and political aims. On Reisch's explanation, the Logical Empiricists who flourished in the Cold War political and academic environment did not consciously modify their philosophical projects in response to a changing ideological climate or more direct political pressure from colleagues. Rather, the Logical Empiricist movement had always contained different styles of philosopher working on different kinds of problems. When Frank was marginalized, what was left over was Carnap's and Reichenbach's more technical style of Logical Empiricism.

Reisch tends to talk about these differences among the Logical Empiricists as if they were nothing more than differences in philosophical styles, or differences in what aspects of a common project various figures chose to emphasize. This is certainly the picture of the movement suggested by the passage from the 1929 Vienna Circle manifesto, from which Riesch takes his book's subtitle. There, Neurath, writing with Carnap and Hans Hahn, allows that

not every single adherent of the scientific world conception will be a fighter. Some glad of solitude will lead a withdrawn existence on the icy slopes of logic; some may even disdain mingling with the masses and regret the "trivialized" form that those matters inevitably take on spreading. (Neurath et al. 1996 [1929], p. 339)

One gets the impression that the difference between Neurath - a "fighter" - and those who are "glad of solitude" is nothing more than a difference of personality. Those without the stomach for Neurath's intellectual brawling may choose to play a different role in the movement and to work on different aspects of Logical Empiricism. Reisch tends to project this picture of different strains within Logical Empiricism into later decades, so that during the Cold War, philosophers of science who manage not to be marginalized are among those in the academy who "opt for" cultural and political disengagement and "the icy slopes of logic" (Reisch 2005, p. 344). On this picture, Neurath and Carnap are said to have "approached scientific philosophy with different skills and values" (Reisch 2005, p. 192), and these approaches are described as Neurath's "interests in empiricism and the unity of the sciences" in contrast with "Carnap's more formal, 'scholastic' style of work" (Reisch 2005, p. 17). In a similar vein, Reisch says that Reichenbach and Feigl "chose" a politically disengaged "direction" for philosophy of science (Reisch 2005, p.284). The differences here are differences in interests, styles, and directions chosen.

But this disagreement in the Logical Empiricist movement was no mere difference in interests or styles. And contrary to another of Reisch's suggestions (Reisch 2005, p. 381), it was not new in the 1950s, or even the 1940s. Rather, the disagreement was one of substantive views about the place of practical, cultural, and political aims in philosophy of science, and it had been part of the Logical Empiricist movement since at least the mid30s, if not before. To be sure, Reisch's Logical Empiricist protagonists-Neurath, Carnap, Reichenbach, Frank-were all committed to the view that science had (or could possibly have) practical aims. But in the 1930s Carnap, unlike Neurath, sought to distinguish between science and philosophy of science in a manner that had precisely this consequence: while science could have cultural and political aims, the philosophy of science could not, and had to remain strictly apolitical and nonpartisan. 


\section{Political Aims and Carnap's Logic of Science}

This view of philosophy is implicit in Carnap's 1934 Logical Syntax of Language, ${ }^{1}$ and it remained central to his views throughout his later writings. In Logical Syntax, as always, Carnap aims to show how traditional metaphysical disputes can be dissolved, and his strategy leads him directly to an explicit recognition of the practical dimensionsincluding the cultural and political dimensions - of scientific knowledge. But for Carnap, while philosophy of science must recognize practical aims in science, it is not philosophy's task to endorse or argue for any of those aims.

Carnap insists that traditional philosophy should be replaced by what he calls the logic of science, the task of which consists in the logically precise investigation of different possible formal systems that might be used in formulating scientific theories. To see how Carnap intends this to dissolve traditional metaphysical problems, consider the case of mind-body problem, or what Carnap calls the psycho-physical problem. In traditional philosophy, advocates of one or another form of physicalism would attempt to argue, say, that mental processes were really (metaphysically!) identical to material processes. But as Carnap sees it, those attempts to argue for philosophical positions will go around and around without ever getting settled decisively. Instead, Carnap thinks, we should construct a formal system that expresses the terms used in the language of psychology, and then we should see if those terms can be reduced, via the terms of biology and chemistry, to the terms of physics (Carnap 2002 [1934]. p. 324). Whether or not the terms of psychology can be reduced to those of physics is a question that we can hope to answer by doing the logical syntax of the languages of psychology and physics.

Carnap means to avoid all metaphysical wrangling about the mind-body problem by seeing the choice to adopt a physicalist language for psychology as a purely pragmatic decision. If we choose to adopt a physicalist language in psychology, our choice is not justified by any argument that physicalism is true. The choice is motivated merely by considerations of what we aim to do with our psychology. Suppose our aims, like Carnap's, are to unify the sciences, to deepen connections between them, and to exclude from them metaphysical abstractions like Volksgeist. Then like Carnap, we might choose to adopt a physicalist language in psychology, since it is a language that will help to do those things. Thus in Logical Syntax, Carnap's way of dissolving traditional philosophical problems is to locate those disputes outside the sphere of rational argument, and in the sphere of pragmatic choices, including choices motivated in part by political considerations.

Reisch sees Carnap's distinction between syntax and pragmatics as a division within philosophy, and so he sees Carnap as allowing a role for practical considerations in philosophy (Reisch 2005, p. 383). However, for Carnap only the logic of science-that is, only syntax - is properly philosophical: ${ }^{2}$ the logic of science is the discipline Carnap offers as a strictly non-metaphysical successor to prior, overly-metaphysical philosophical investigations of science. As he puts it, "the logic of science takes the place of the inextricable tangle of problems which is known as philosophy" (Carnap 2002 [1934]. p. 279; emphasis in original). When philosophy has its metaphysical problems dissolvedthat is, when those problems are understood properly as merely pragmatic questions about

\footnotetext{
${ }^{1}$ Reichenbach, in his 1938 Experience and Prediction, also excludes practical aims from philosophy of science. For reasons of space, my discussion is limited to Carnap.

${ }^{2}$ Carnap would later expand the domain of the philosophical so as to include semantics as well and syntax. See (Carnap 1947). The important point for my purposes is that never he takes pragmatic considerations to be properly philosophical.
} 
what languages we should adopt—all that remains of philosophy is the logic of science. But the logic of science is only the formal investigation of different languages. It is not in the business of evaluating the various pragmatic considerations that could weigh in favor of some languages and against others.

To be sure, Carnap thinks the pragmatic dimensions of knowledge can be investigated-just not by philosophy. Rather, he suggests that their investigation is carried out by history, psychology, and sociology (Carnap 2002 [1934], p. 279). The history, psychology, and sociology of science, along with Carnap's logic of science constitute what he calls the "theory of science" (Carnap 2002 [1934], p. 279)—something like what we would call science studies. But for Carnap, only one part of the theory of science is philosophy, namely, the logic of science.

We need to be careful about how we understand Carnap here. In a certain sense, of course a philosopher may endorse or recommend one language of science over another, and may do so with cultural or political aims in mind. In fact, Carnap does just this: in consistently advocating for empiricist or physicalist constraints on languages allowed in psychology, he aims among other things to rule out the possibility of a socially regressive psychology employing nationalistic conceptions of the Geist of a Volk. But in an important sense, Carnap cannot consider this advocacy philosophy. That is, when Carnap engages in this advocacy, he does so, by his own lights, without his philosopher's hat on. ${ }^{3}$ Advocating pragmatic considerations in favor of the adoption of one language over another is not something that can be done within the logic of science, which Carnap thinks is all that remains of philosophy. The task of the philosopher of science-considered as a philosopher of science-is only to construct and elaborate those languages, so as to be able to tell the scientist, for example, "If you want to exclude socially regressive nationalistic abstractions from your psychology, you can use this language to do that." On Carnap's conception of philosophy of science, it is neutral with respect to pragmatic aims, including cultural and political ones. So in distinguishing between pragmatics and the logic of science, Carnap rules out the possibility of political aims in philosophy properly so-called.

\section{Philosophy of Science with Cold War Liberal Aims?}

Within the Logical Empiricist movement, then, there was substantive disagreement about the role that politics can play in philosophy of science: whereas for Neurath philosophy of science could have political aims, for Carnap it could not. Things get more complicated when we add to this mix the views of some American philosophers in the 1940s.

As Reisch makes clear, philosophers in the post-War years such as Horace Kallen and Sidney Hook shared with the Logical Empiricists a broad commitment to Enlightenment ideals. Coming from a philosophical context dominated by John Dewey, they agreed with the Logical Empiricists that science could be an instrument of social progress. In the 1930s Kallen and Hook also shared Neurath's and Carnap's interest in collectivist, socialist politics. In fact, Reisch makes a persuasive case that these points of agreement between the Logical Empiricists and American philosophers such as Kallen and Hook explains a great deal about why Logical Empiricism flourished when it was transplanted from its European to its new North American context. But during the 1940s, both Kallen's and Hook's politics underwent a shift common to American leftist intellectuals of the time. Disillusionment over the brutality of Stalin's Soviet Union turned them into full-throated

\footnotetext{
3 The interpretation of Carnap's mature view I am glossing here is defended in detail in (Ricketts 1994).
} 
anti-communists and champions of liberal democratic values. By the time the Cold War set in, they were ready to be liberal Cold Warriors.

While Hook was not by our lights principally a philosopher of science, his career nevertheless offers us glimpses of what a Cold War liberal philosophy of science might have looked like. Hook was interested in the human and social sciences, writing and editing works about psychology and scientific method (Hook 1959), as well as philosophy of economics (Hook 1967); and he was also interested in the role values can and should play in scientific research (Hook et al. 1977). But more broadly, Hook took himself to share with Dewey the conviction that philosophy should concern itself with "two themes" in modern culture. Those themes were:

first, the nature of scientific inquiry and its implications for man's conception of himself, and the cosmos; and, second, the aspiration for a world of free men and free societies which despite the triumphs of totalitarian regimes in the world is stronger in popular consciousness than ever before in human history. (Hook 1950, p. vi)

Philosophy, on Hook's view, had to be engaged with both science and liberal politics. What is important for my purposes is to see how Kallen's and Hook's views compare to those of the various Logical Empiricists. On the question of political commitments, we find Kallen's and Hook's anti-communism opposed to the collectivist and internationalist commitments of Neurath, Carnap, and Frank. However, on the question of the role that politics can play in philosophy, we find Carnap's apolitical stance opposed not just to Neurath and Frank's views, but to Kallen's and Hook's too. For Kallen and Hook shared with Neurath's and Frank the view that philosophy-including philosophy of scienceand not just science, is committed to the project of advancing Enlightenment ideals. To be sure, these two groups disagreed about which ideals were centrally important to this project: Neurath was committed to promoting social progress through rational, scientific planning, whereas Kallen and Hook were committed to the absolute freedom of the individual. But in contrast to Carnap and others such as Reichenbach, Feigl, and Hempel, they agreed that philosophy had cultural and political aims. So we have three possible visions for philosophy of science here: Neurath's and Frank's leftist philosophy of science; philosophy of science in the mold of Kallen's and Hook's liberal, anti-communist philosophy; and Carnap's and others' culturally and political disengaged philosophy of science.

\section{What Do Cold War Political Forces Explain?}

With these three possible positions in view, we can see exactly what Reisch's account does and does not explain about how Cold War political forces changed philosophy of science. By the 1950s the Logical Empiricists' political commitments - their internationalism and their belief in scientific planning as an instrument of social progress-were out of step with American cultural currents. But more than this, as Reisch shows, leaders of the Logical Empiricist movement were attacked by Cold War liberals. Consider an instance of this. As Reisch explains, starting in 1939 and continuing until Neurath's death in 1945, Kallen criticized Neurath's idea of the unity of science as politically dangerous: calls for unity can be calls to stifle dissent, a rhetorically elevated way of telling people to shut their mouths and fall in line. "Unity" was a watchword of totalitarianism. For Kallen, scientists, no less than citizens of liberal democracies, had to be free to disagree with one another (Reisch 2005, p.169-186). This episode shows how, even before the Cold War had begun, 
American philosophy was already becoming hostile to Neurath's style of politically engaged philosophy of science. Reisch sets particular episodes like this one against a broader intellectual background characterized by giants like William F. Buckley and Friedrich Hayek. The resulting picture gives a satisfying explanation of why Neurath's and Frank's brand of politically engaged philosophy of science could not flourish in Cold War America.

But Riesch aims to explain something else besides the marginalization of Neurath's program as it was carried out by Frank following Neurath's death. He also wants to explain why the philosophy of science that did flourish during the Cold War was the apolitical, culturally disengaged philosophy practiced by figures like Carnap. Over the course of the 1950s, key aspects of Carnap's and others' views of philosophy of science were consolidated as partly definitive of the discipline. For example, remember Carnap's view that the properly philosophical study of science is distinct from political considerations, as well as from psychological, sociological, and historical considerations. As Reisch notes, it is precisely this view of philosophy of science that May Brodbeck is at pains to articulate in her introduction to her and Feigl's 1953 reader, Readings in the Philosophy of Science (Brodbeck 1953, pp. 3-7). On Resich's explanation, Carnap's program in philosophy of science flourished in the 1950s for much the same reason that Frank's Neurathian program was marginalized: Cold War cultural and political forces were responsible for how philosophy of science changed in that period.

But as Reisch's own account suggests, Cold War political forces cannot explain why Carnap's program would have been seen as the only game in town. Kallen and Hook offered a vision of philosophy with Cold War liberal commitments, engaged with both politics and science. So we need to ask at this point why Carnap's program become so overwhelmingly dominant that it excluded any philosophy of science in the mold of Kallen's and Hook's philosophy. Why was there no room in philosophy for a politically engaged philosophy of science, reoriented towards the ideals of Cold War liberalism? Consider once more Kallen's criticism that Neurath's philosophy of science tended towards totalitarianism. While this early episode illustrates the political pressure exerted on the Logical Empiricists, it also shows that the intellectual context was not hostile to politically engaged philosophy of science per se. After all, even Cold Warriors like Kallen and Hook took themselves to be doing exactly that-politically engaged philosophy, including politically engaged philosophy of science. The Cold War intellectual context was hostile only to the Logical Empiricists' particular political commitments. So when Cold War anti-communist political pressures were exerted on politically engaged philosophy of science, why wasn't the effect to make space for and foster politically engaged, Cold War liberal philosophy of science?

Riesch's explanation has a selectionist form (Riesch 2005, p. xii), and it might make sense to say something like this. The Logical Empiricist movement was dominant in American philosophy of science in the 1940s. The affect of Cold War political forces was to marginalize just those parts of the movement that took their philosophy to have cultural and political aims. The parts of the movement that saw philosophy of science as apolitical avoided being marginalized, and so their dominance continued unabated, and in fact was consolidated. This response is not entirely satisfying, though. After all, the sustained and consolidated dominance of a particular version of Logical Empiricism is precisely what we want explained. Why did Carnap's vision of an apolitical philosophy of science come to dominate so completely that by the 1960s, if not before, there was no place in philosophy of science even for Kallen's and Hook's style of Cold War liberal philosophy? 


\section{Professionalization, Specialization, and Philosophical Method}

Recent work on the politics of Cold War philosophy of science has suggested that its political changes relate in some way to the wave of professionalization ${ }^{4}$ that philosophy of science underwent in the years following the war. Philip Mirowski has suggested that professionalization in philosophy of science was a consequence of philosophers adopting the technical, nonpartisan analytical methods of operations research (Mirowski 2005, p. 301). Don Howard seems to suggest close to the opposite, that the dominance of apolitical philosophy of science is explained in part by the professionalization of the discipline (Howard 2003, pp. 72-73). Reisch, too, suggests a connection between philosophy of science shedding its political commitments and its increasing professionalization following the war (see, for example, Reisch 2005, p. 387).

But whether or not an appeal to professionalization helps here depends on what we take professionalization to be. If we are interested in the relation between professionalization and political disengagement, we cannot assume at the outset that a professional philosopher of science must be politically disengaged. Besides simply defining away the question at issue, it would be wrong to see the professions as culturally or politically disengaged. Doctors and lawyers are routinely actively engaged in political and policy advocacy. To take a recent example from the Unites States, in August of 2006 the American Medical Association (AMA) issued press releases applauding the FDA's approval of Plan B emergency oral contraceptive for over the counter sales. ${ }^{5}$ Given that the AMA's press release opposed the Bush administration's policy on the drug, it constitutes advocacy in a politically charged context. While professions might have particular or circumscribed modes of cultural and political engagement, we cannot assume that professional philosophers of science-just in virtue of being professionals-must be politically disengaged.

We find more promising ideas when, in a Neurathian spirit, we look to the professions literature in sociology for help. It is uncontroversial in the professions literature that a profession has "monopolistic control" (Freidson 2001, p. 32) over its work. Its work is its "jurisdiction" (Abbott 1988, ch. 3). Among other things, this means that a profession can control who gains entry into the profession and the standards by which members are judged competent. In many cases - think of doctors or lawyers-a profession can call on the state to prevent non-members from practicing. Although philosophers of science, and academics more generally, cannot do that, they do enjoy a great deal of autonomy in their work. But crucially, this autonomy, this ability of a profession to control its own work, is possible only if the profession does work that is valued by groups or institutions with the resources to support it, and whose interests the profession's autonomy does not undermine.

Here is one place where the concept of professionalization gets its purchase for Reisch's account: Neurath's and Frank's style of collectivist, internationalist scientific philosophy

\footnotetext{
${ }^{4}$ I prefer to speak of a "wave of professionalization," rather than simply "professionalization," since it more clearly allows that the process is one that admits of degrees. This is especially important when talking about philosophy of science in the 1950s, since, as Reisch's account makes very clear, philosophy of science was already a professional discipline in America at least by the 1930s, and probably well before that: philosophers were employed by universities to teach courses on the methodology of science, they wrote textbooks about the methodology of science, and they published articles in journals such as William Malisoff's Philosophy of Science. In the German-speaking world, this level of professionalism in philosophy of science had been in place since the mid-19th Century. But, if we have the right model of professionalization, there is no problem in recognizing this, and at the same time thinking Cold War philosophy of science became more professional. Thanks to Gary Hatfield for pressing me on these and related points.

5 American Medical Association, "AMA applauds FDA approval of OTC access for Plan B," August 24, 2006. http://www.ama-assn.org/ama/pub/category/16734.html
} 
could not undergo a wave of professionalization during the Cold War, because it did not do work that was ultimately valued by, say, funding agencies like the Rockefeller Foundation, which terminated its funding for Frank's Unity of Science Institute in 1955 (Reisch 2005, p. 308). At the same time, we still do not have a satisfying account of why Carnap's politically disengaged philosophy of science came to dominate professional philosophy of science, and why there was no room for a philosophy of science in the mold of Kallen's and Hook's liberal philosophy. For the political stance of Kallen's and Hook's philosophy was one that was valued-so much so, in fact, that Hook eventually received the Presidential Medal of Freedom from Ronald Reagan (Reisch 2005, p. 364).

If the idea of a profession's jurisdiction or monopoly on its work is no help, another important feature of professionalization is. Recent work on the professions has emphasized their high degree of specialization. But crucially, the professions do not do just any kind of specialized work. Their work must be specialized in the right way, since a factory worker who spends all day every day putting one size of nut onto one size of bolt also has very specialized work. The difference between the factory worker and the professional is that the professional's work is based in, or informed by abstract theory. How the theory is used by the professional requires an ineliminable element of judgment-it cannot be standardized. Work that is at once highly specialized and involving abstract enough theory that it cannot be standardized is thus professional work. Notice, too, that the abstract, theoretical dimension of professional work explains why the professions require formal training. ${ }^{6}$

The relationship between a profession's specialization and the abstract theory that informs its work is no accident. A profession is (at least partially) defined by the character of the abstract knowledge it uses. This body of knowledge serves to provide the profession with its own methods of diagnosis, treatment—and especially relevant for philosophers-analysis and inference (Abbott 1988, pp. 52-55). These methods (at least partially) determine the boundaries of the profession. They determine its jurisdiction, the area of work it controls. They determine what will count as the work done by the profession and what will not.

The idea of a specialization defined by an abstract body of theory is helpful. In particular, it is model of professionalization that helps us understand what it might mean to say that philosophy of science underwent a wave of professionalization over (roughly) the 1950s. Consider how philosophy of science changed during that period. As Reisch makes clear, philosophy of science in the 1930s had many tasks. In general, we might say it offered learned commentary on science and its place in society. This included engaging with the history of science, the sociology of science, and the psychology of science. It also included engaging with the sciences themselves, hopefully even by collaborating with working scientists. Finally, it included popularizing important scientific theories and results. But by the end of the 1950s, it had fragmented into more specialized sub-disciplines. Think again of Brodbeck's introduction to her and Feigl's reader: she explicitly distinguishes philosophy of science from history of science and sociology of science. By the end of the 1950s, philosophy of science was a much more specialized, more narrowly conceived discipline than it had been in the 1930s. This specialization is one mark of a wave of professionalization.

\footnotetext{
${ }^{6}$ Sociologists in the first half of the 20th Century took these institutional characteristics to be definitive of the professions themselves. See for example (Car-Saunders \& Wilson 1933) and (Wilensky 1964). One problem with this type of model is the way it naturally extends to include vocations that pre-theoretically, we do not consider professions. Mechanics can attend community college classes in order to learn their trade. Hairdressers go to hairdressing schools in order to receive certifications that are widely recognized in their field. (This problem was noticed in [Wilensky 1964]). More recent models of the professions avoid these problems by focusing on distinctive aspects of the character of the professional's work itself.
} 
But moreover, the boundaries of the increasingly specialized philosophy of science were determined, at least in part, by a conception of philosophy that marked off some methods of analysis and inference as distinctly philosophical. Consider another important reader coedited by Feigl, his and Sellars' 1949 Readings in Philosophical Analysis. It is far from clear that the authors collected there took themselves to be using the same philosophical method. For example, we find C.L. Stevenson's analysis of moral terms, as well as Carnap's proposal to use logical syntax with the aim of unifying the language of science. The first of these methods is concerned in the first instance with natural languages, whereas the second sets natural language aside and offers formal, rational reconstructions instead. Nevertheless, in the preface to their reader, Feigl and Sellars take these, along with the various other essays they include, as exemplars of something they call "philosophical analysis." Feigl's chapter called "Logical Empiricism," which appeared on its own in 1943, but serves as an introduction in the 1949 anthology, makes it clear that philosophical analysis is really logical or linguistic analysis. ${ }^{7}$ Along similar lines, Arthur Pap claims in a textbook that appeared the same year as Feigl and Sellars' reader that if we take the term "philosophy" to mean anything "distinct from experimental science and mathematical reasoning, it can only mean logical analysis" (Pap 1949, p. 6).

While philosophy's boundaries were determined by the idea of logical or linguistic analysis, philosophy of science was becoming consolidated as a sub-discipline of philosophy on this conception. Philosophy of science, as Pap presents it in several chapters of his 1949 textbook, is the analysis of concepts such as probable inference, causality, and explanation. In her preface to her and Feigl's reader, Brodbeck sees the task of philosophy of science as "the logical analysis of scientific concepts, laws, and theories" (Brodbeck 1953, p. 5). Pap's and Brodbeck's views of philosophy of science sit well with Ernst Nagel's, as he explained them in his 1961 The Structure of Science. Nagel begins the preface to his book with a short discussion of various things in the history of philosophy that could be called "philosophy of science," but then explains that his project will be one of analyzing the logic of scientific inquiry and the logical structure of its intellectual products" (Nagel 1961, viii). For philosophers of science like Pap, Brodbeck, and Nagel, philosophy of science was the logical analysis of scientific concepts, and so was a part of philosophy understood as logical analysis. As Pap put it in a 1962 textbook specifically about philosophy of science, philosophy of science is "indistinguishable from analytic philosophy except that the analysis is restricted to concepts and problems that are especially relevant to science" (Pap 1962, p. v).

This conception of philosophical analysis determines both what is and is not philosophy of science. Or as Nagel puts is, the "scope" of his interests are "controlled by" the idea of logical analysis of scientific concepts (Nagel 1961, viii). If philosophy of science is the logical analysis of scientific concepts, then it is not an empirical discipline. It is, as Brodbeck argues, distinct from psychological, sociological, and historical investigations of science. ${ }^{8}$ The increasing specialization of philosophy of science is here determined by a particular conception of philosophical method.

\footnotetext{
7 Thanks to Jason Rheins and Alan Richardson for helpful discussion on these points.

8 The desire to mark off philosophy of science as distinct from the history, sociology, and psychology of science explains why these do not emphasize the philosopher of science's need for a specialized knowledge of the content of actual science. While in the 1950s as now, such knowledge was important for a professional philosopher of science, it is no less important for the historian of science. So the abstract theory that determined the boundaries of an increasingly specialized philosophy of science could not have been knowledge of the content of science.
} 
An "epilogue" that Pap includes in his 1949 textbook is even more telling for our purposes. He considers the "widely felt" idea that analytic philosophers "lack a sense of social responsibility" and that they ignore philosophy's "important social function" (Pap 1949, p. 477). Revealingly, his response is not to deny this outright. He concedes that "[a]nalytic philosophy can hardly affect society in such direct ways" as great speculative worldviews have in the past. Analytic philosophy's impact on society and politics is indirect. It can perform the "function of curing people from intellectual confusions through special attention to the inexhaustible sources of abusing language, and of producing habits of sober, clear thinking and speaking..." (Pap 1949, p. 477). Pap thinks that because philosophy is logical and linguistic analysis, its engagement with social questions is limited. Its role is only to clarify those questions.

Pap's views echo Feigl's, as he explains them in the essay on Logical Empiricism that serves as an introduction to his and Sellars' reader. Feigl opens the essay by reviewing some of the philosophical traditions and tendencies that have been incorporated into Logical Empiricism. One of those, familiar from Reisch's account, is the Enlightenment tradition embodied by Neurath and his Encyclopedia of Unified Science. Here is how Feigl describes Neurath's program within Logical Empiricism: "The tradition they now represent has centered its chief inquiries around the two humble questions, 'What do you mean?' and 'How do you know?'” (Feigl 1949, p. 5). But what about Neurath's social and political aims? What about Neurath's scientific worldview? As Feigl sees it,

[n]either the construction of a world view nor a vision of living is a primary aim. If through the progress of knowledge and through social, political, and educational reform one or the other objective is pursued, philosophy in its critical and clarifying capacity may aid or guide such developments. But it cannot, by mere reflective analysis, prescribe or produce them (Feigl 1949, p. 5; emphasis in original).

Feigl has characterized Neurath's unity of science program in terms that Neurath would surely not countenance. Rather than Neurath's view of philosophy, this is Feigl's own view, and there are two things about it we need to see. First, philosophy does not here have the task of making prescriptions for or aiming to bring about social progress. But second, philosophy's aims are limited precisely by its method: philosophy's method is "mere reflective analysis"-logical or linguistic analysis-but, Feigl claims, that analysis can never issue prescriptions. No less than Pap's conception, Feigl's conception of philosophical method rules out the possibility of social and political engagement.

We cannot conclude too much just from Pap's epilogue and Feigl's essay, but they are nevertheless suggestive. If in fact a conception of philosophical analysis was being consolidated as Feigl's essay was reprinted in 1949, then we have at least a hint about how professionalization might relate to the marginalization of politically engaged philosophy of science. The conception of logical and linguistic analysis as philosophical analysis could have functioned as the abstract theory that determined the boundaries of philosophy as a specialized discipline. That is, it would have determined the boundary of professional philosophy: philosophy's method was logical or linguistic analysis, so tasks that could not be carried out by that method fell outside the purview of philosophy. ${ }^{9}$ But Kallen's and

\footnotetext{
${ }_{9}$ Notice too that Feigl selected his essay to introduce a reader whose purpose, he and Sellars explain in their preface, was to respond to "the perennial complaints of philosophy teachers" about "the dearth of readily accessible and worthwhile reading material in modern philosophical analysis" (Feigl \& Sellars 1949, p. v). The introductory essay and those that follow it were intended to train students in what Feigl and Sellars considered philosophy.
} 
Hook's politically engaged philosophy, no less than Neurath's or Frank's, would have fallen on the wrong side of the boundary. There would have been no place for their cultural or political engagement in the increasingly professionalized philosophy of science.

\section{Further Questions}

Time to take stock. I have suggested that as early as the mid-1930s, if not before, there was a substantive disagreement among the Logical Empiricists about the role of political aims in philosophy of science. For Logical Empiricists like Neurath, philosophy of science aimed to bring about cultural and political progress. But Logical Empiricists like Carnap drew a line between science and the philosophy of it, and for them, only science could have cultural or political aims. Recognizing this disagreement helps bring into view certain questions about Reisch's account of how Cold War political forces changed philosophy of science. Why would Carnap's style of politically disengaged philosophy of science have become so dominant that it excluded a philosophy of science in the mold of Hook's style of Cold War liberal philosophy? What about the Cold War political and intellectual climate can explain why philosophy of science did not simply trade its collectivist and internationalist politics for the politics of Cold War liberalism?

Help with these questions comes when we think about the wave of professionalization that philosophy underwent as it was disengaging politically. Reisch shows in detail how, in the post-war years and throughout the 1950s, philosophy of science became more and more specialized. It shed its concerns with history and sociology, as well as its concerns with popularization and pedagogy.

But moreover, thinking about how exactly philosophy of science specialized-what influences on it determined what would count as philosophy of science and what would not-points us in a useful direction. It points, among other places, to the consolidation of philosophy of science as a sub-discipline of philosophy just when Anglo-American philosophy was defining itself by a method of logical or linguistic analysis. If this much is right, then a better understanding of Cold War philosophy of science will come from broadening the scope of our history so as to include Anglo-American philosophy as a whole. How did philosophy professionalize after the war? How did philosophical styles as diverse as G.E. Moore's common sense philosophy and Carnap's logical syntax come to be seen as having a single "conception of philosophical analysis underlying" them (Feigl and Sellars 1949, p. vi)? What did this new conception of a shared method mean for culturally or politically engaged philosophy, and for philosophy's engagement with the rest of the academy? If we want to understand why the Cold War saw a politically disengaged philosophy of science rise to overwhelming dominance, and if we want to understand the role of professionalization in that process, history of philosophy of science will not be history of philosophy enough.

\section{References}

Abbott A (1988) The system of professions: an essay in the division of expert labor. Chicago University Press, Chicago, IL

Brodbeck M (1953) The nature and function of philosophy of science. In: Feigl H, Brodbeck M (eds) Readings in the philosophy of science. Appleton, Century, Crofts, New York, NY, pp 3-7

Car-Saunders AP, Wilson PA (1933) The professions. Oxford University Press, Oxford

Carnap R (2002) [1934], The logical syntax of language, Amethe Smeaton (trans.). Open Court, Chicago, IL 
Carnap, R (1947) Empiricism, semantics, and ontology. In: Meaning and necessity: a study in semantics and modal logic. University of Chicago Press, Chicago, IL, pp 205-221

Feigl H (1949) [1943], Logical empiricism. In: Feigl H, Sellars W (eds) Readings in philosophical analysis. Appleton, Century, Crofts, New York, NY, pp 3-26

Feigl H, Sellars W (1949) Readings in philosophical analysis. Appleton, Century, Crofts, New York, NY

Freidson E (2001) Professionalism, the third logic: on the practice of knowledge. Chicago University Press, Chicago, IL

Hook S (ed) (1950) John Dewey: philosopher of science and freedom. The Dial Press, New York, NY

Hook S (ed) (1959) Psychoanalysis, scientific method, and philosophy. New York University Press, New York, NY

Hook S (ed) (1967) Human values and economic policy. New York University Press, New York, NY

Hook S, Kurtz P, Todorovich M (1977) The ethics of teaching and scientific research. Prometheus, Buffalo, $\mathrm{NY}$

Howard D (2003) Two left turns make a right: on the curious political career of north American philosophy of science at midcentury. In: Hardcastle GL, Richardson AW (eds) Logical empiricism in north America. University of Minnesota Press, Minneapolis, MN, pp 25-93

Nagel E (1961) The structure of science: problems in the logic of scientific explanation. Harcourt, Brace, and World, New York, NY

Neurath O, Hahn H, Carnap R (1996) [1929] The scientific conception of the world: the Vienna circle. M. Neurath \& P. Foulkes (trans). In: Sarkar S (ed) The emergence of logical empiricism: from 1900 to the Vienna circle, Garland, New York, NY, pp 321-340

Mirowksi P (2004) The scientific dimensions of social knowledge and their distant echoes in 20th century American philosophy of science. Stud Hist Philos Sci 35:283-326

Pap A (1949) The elements of analytic philosophy. MacMillan, New York, NY

Pap A (1962) An introduction to philosophy of science. Free Press of Glencoe, New York, NY

Reichenbach H (2006) [1938] Experience and prediction. University of Notre Dame Press, Notre Dame, IN

Reisch GA (2005) How the cold war transformed philosophy of science: to the icy slopes of logic. Cambridge University Press, Cambridge

Ricketts T (1994) Carnap's principle of tolerance, empiricism, and conventionalism. In: Clark P, Hale B (eds) Reading Putnam. Basil Blackwell, Oxford, pp 176-200

Wilensky HL (1964) The professionalization of everyone? Am J Sociol 70(2):137-158

\section{Author Biography}

Scott Edgar is a doctoral student in philosophy at the University of Pennsylvania. 